\title{
KEHALALAN DAGING AYAM POTONG DI PASAR TRADISIONAL KOTA MEDAN
}

\author{
Anwar Sadat Harahap ${ }^{1)}$, Alkausar Saragih ${ }^{2)}$, Disna Anum Siregar ${ }^{3)}$ \\ UMN Al Washliyah Medan ${ }^{1)}$ \\ UMN Al Washliyah Medan ${ }^{2}$ \\ UMN Al Washliyah Medan ${ }^{3)}$
}

\begin{abstract}
ABSTRAK
Sebagian besar penjual ayam potong di pasar tradisional yang ada di kota Medan melakukan pemotongan ayam sambil merokok, bercerita dan dilakukan dengan sendirian, tanpa bantuan orang lain. Bahkan yang lebih miris lagi bahwa ayam yang baru saja disembelih belum benar-benar mati dan kaki dan sayapnya masih terlihat bergerak-gerak, sudah dimasukkan ke dalam tong yang berisi air panas untuk dilakukan pembersihan bulu-bulunya. Kondisi ini dilakukan untuk sekedar mengejar target jumlah ayam yang harus disembelih pada setiap harinya. Metode pelaksanaan yang digunakan oleh tim Program Kemitraan Masyarakat (PKM) dengan mitra (MUI Kota Medan) adalah: 1) Menggunakan pendekatan pendampingan terhadap pedagang ayam potong di pasar tradisional Kota Medan, 2) Melaksanakan pelatihan tentang tata cara penyembelihan hewan berdasarkan Syariat Islam, 3) Melaksanakan penyuluhan hukum dengan mengggunakan metode ceramah dan tanya jawab. Hasil yang telah dicapai dalam pelaksanaan Program Kemitraan Masyarakat (PKM) ini adalah a) Terbentuknya 3 (tiga) Kelompok Pedagang Cinta Produk Halal (KPCPH) di pasar tradisional Kota Medan yang disahkan oleh Ketua MUI Kota Medan, b) Penerbitan Buku Panduan Tentang Tata Cara Penyembelihan Hewan secara halal yang menjadi pedoman bagi masyarakat dan KPCPH, c) Karya Tulis Ilmiah yang dimuat dalam jurnal nasional terakreditasi ,d) Meningkatkan pemahaman masyarakat, terutama pedagang daging ayam potong tentang tata cara penyembelihan hewan yang baik dan halal.sebagaimana diatur dalam Undang-undang Nomor 33 Tahun 2014 Tentang Jaminan Produk Halal. Adapun kegiatan yang dilaksanakan dalam PKM ini: a. Pelatihan tentang tata cara penyembelihan hewan kepada para pedagang daging ayam potong, b. Penerbitan sertifikat yang diterbitkan MUI Kota Medan Tentang kelayakan dalam melakukan penyembelihan ayam potong bagi para pedagang yang melakukan penyembelihan ayam potong, c. Penyuluhan hukum tentang tata cara penyembelih ayam potong di pasar tradisional Kota Medan.
\end{abstract}

Kata Kunci: Kehalalan, Daging Ayam Potong, Pasar tradisional

\begin{abstract}
Most broiler chicken sellers in traditional markets in the city of Medan slaughter chickens while smoking, telling stories and carried out carrying, without the help of others. Even more sad again to the chicken that has just been slaughtered has not really died and legs and wings are still seen moving, has been put in a barrel filled with hot air to be done to save the feathers. This condition is carried out to achieve the target number of chickens to be slaughtered at each meeting. The Implementation Methods used by the Community Partnership Program (PKM) team with partners (MUI Medan City) are: 1) Using assistance to broiler chickens in the Medan traditional market, 2) Carrying out training on procedures for slaughtering animals based on Islamic Sharia, 3 ) Carry out legal discussions by using the lecture and question and answer method. The results that have been achieved in the implementation of the Community Partnership Program (PKM) are a) Establishment of 3 (three) Halal Product Traders Group (KPCPH) in the Medan City traditional market which was approved by the Chairperson of the Medan City MUI, b) Issuance of Guidebook on Procedures Animal Slaughter which is a guideline for the community and KPCPH, c) Scientific Writing published in accredited national journals, d) Gaining public understanding, especially chicken meat traders, produces procedures for slaughtering animals that are good and lawful. Act No. 33 of 2014 concerning Guarantees Halal Products. Activities carried out in this PKM: a. Training on how to slaughter animals for broiler chicken meat traders, b. Issuance of certificates issued by Medan City MUI Regarding the feasibility of slaughtering broilers for traders who
\end{abstract}


slaughtering broilers, c. Legal education regarding the procedure for the slaughtering of broilers in the traditional markets of Medan City.

Keywords: Objection, Cut chicken, Traditional market

\section{PENDAHULUAN}

Hasil penelitian Hibah Bersaing Anwar Sadat Harahap Tahun 2009 dengan judul:"Kajin Hukum Islam Terhadap jual Beli Daging di Kota Medan”, menyimpulkan bahwa sebagian besar penjual ayam potong di pasar tradisional yang ada di kota Medan melakukan pemotongan ayam sambil merokok, bercerita dan dilakukan dengan sendirian, tanpa bantuan orang lain. Bahkan yang lebih miris lagi bahwa ayam yang baru saja disembelih belum benar-benar mati dan kaki dan sayapnya masih terlihat bergerak-gerak, sudah dimasukkan ke dalam tong yang berisi air panas untuk dilakukan pembersihan bulubulunya. Kondisi ini dilakukan untuk sekedar mengejar target jumlah ayam yang harus disembelih pada setiap harinya.

Memang menurut kajian ilmu kesehatan, daging ayam potong semacam ini layak dikonsumsi, karena dagingnya bersih dan masih segar. Namun, dalam mengkonsumsi daging ayam potong, bukan hanya dilihat dari sudut pandang kebersihan dan kesegaran dagingnya semata, melainkan perlu juga diperhatikan status kehalalan dagingnya, supaya orang yang mengkonsumsinya mendapatkan kesehatan dan keberkahan dalam kehidupan seharihari.

Penyembelihan hewan secra baik dan benar berdasarkan ketentuan hukum Islam merupakan kewajiban bagi para pedagang daging hewan, termasuk pedagang daging ayam potong sebagaimana diatur dalam pasal pasal 19 ayat (1) yang berbunyi bahwa hewan yang digunakan sebagai bahan Produk wajib disembelih sesuai dengan syariat dan memenuhi kaidah kesejahteraan hewan serta kesehatan masyarakat veteriner. Selain itu, perolehan makananan yang halal, seperti daging ayam potong mempunyai tujuan untuk memberikan kenyamanan bagi masyarakat sebagaimana diatur dalam Pasal 3 poin"a" berbunyi bahwa penyelenggaraan jaminan produk halal bertujuan untuk memberikan kenyamanan, keamanan, keselamatan, dan kepastian ketersediaan Produk Halal bagi masyarakat dalam mengonsumsi dan menggunakan produk. Dalam poin "b" disebutkan untuk meningkatkan nilai tambah bagi Pelaku Usaha untuk memproduksi dan menjual Produk Halal.

Perhatian terhadap jaminan kehalalan daging ayam potong yang di jual di pasar tradisional Kota Medan merupakan amanah Undangundang Nomor 33 Tahun 2014 pada pasal 4 yang berbunyi bahwa produk yang masuk, beredar, dan diperdagangkan di wilayah Indonesia wajib bersertifikat halal.

Daging yang baik menurut Syariat Islam adalah selain daging ayamnya segar dan higienis, juga daging ayamnya harus halal. Daging ayam potong yang halal adalah apabila disembelih menurut tuntunan Hukum Islam. Sebaliknya daging ayam potong yang tidak disembelih menurut tata cara yang benar sebagaimana diatur dalam Syariat Islam adalah dagingnya haram sebagaimana disebutkan dalam Pasal 
18 ayat (1) poin "d" yang berbunyi bahwa bahan yang berasal dari hewan yang diharamkan sebagaimana dimaksud dalam Pasal 17 ayat (3) adalah hewan yang disembelih tidak sesuai dengan syariat.

Jadi penyembelihan daging ayam potong berdasarkan syariat Islam merupakan amanah undangundang Nomor 33 Tahun 2014 Tentang Jaminan Produk Halal. Sedangkan kriteria penyembelihan yang diatur dalam syariat Islam sebagai berikut:

1. Dimulai dengan dengan membaca

kalimat"Bismillahirrahmaanirrah iim" yang dilanjutkan dengan membaca niat sengaja aku menyembelih ayam karena Allah Ta`ala";

2. Menghadapkan badan ayam yang akan disembelih ke arah kiblat sambil memegang kedua sayat dan kakinya;

3. Menyembelih leher ayam sampai terputus kerongkongan dan segala urat yang ada di sekitar lehernya;

4. Menggunakan pisau yang tajam;

5. Tidak boleh berbicara;

6. Tidak boleh dimasukkan ke dalam air panas sebelum nyatanyata ayamnya telah mati dengan sesungguhnya.

Keenam tata cara penyembelihan di atas menjadi kriteria yang menentukan kehalalan daging suatu hewan menurut Syariat Islam. Jika keenam kriteria di atas dilaksanakan dengan baik, maka daging ayam potongnya masuk kategori halal. Sebaliknya jika kriteria di atas tidak dilaksanakan, maka daging ayamnya masuk kategori daging yang tidak halal untuk dimakan.

\section{METODE PELAKSANAAN}

Metode pelaksanaan yang digunakan oleh tim Program Kemitraan Masyarakat (PKM) dengan mitra (MUI Kota Medan) adalah: 1) Menggunakan pendekatan pendampingan terhadap pedagang ayam potong di pasar tradisional Kota Medan, 2) Melaksanakan pelatihan tentang tata cara penyembelihan hewan berdasarkan Syariat Islam, 3) Melaksanakan penyuluhan hukum dengan mengggunakan metode ceramah dan tanya jawab tentang : a) Materi hukum yang terkandung dalam Undang-undang Nomor 33 Tahun 2014 Tentang Jaminan Produk Halal, b) Tata cara penyembelihan hewan menurut Syariat Islam, c) Jenis makanan, minuman, obatobatan dan kosmetika yang halal menurut Syariat Islam, d) Prosedur pengurusan label halal ke Kantor MUI Kota Medan, e) Persyaratan yang diperlukan dalam pengurusan label halal ke Kantor MUI Kota Medan, f) Manfaat mengkonsumsi makanan halal bagi manusia, g) Cara mengenali makanan halal dalam Islam.

\section{HASIL DAN PEMBAHASAN}

Hasil pelaksanaan Program Kemitraan kepada Masyarakat ini adalah bahwa telah dilakukan berbagai kegiatan sebagai solusi dalam menyelesaikan berbagai permasalahan mitra sebagaimana dipaparkan pada bab sebelumnya. Adapun beberapa kegiatan yang telah dilaksanakan dalam rangka penyelesaian permasalahan mitra sebagai berikut:

1. Solusi yang dilakukan dalam menyelesaikan permasalan pertama adalah dengan 
melaksanakan pelatihan tentang tata cara penyembelihan ayam potong secara benar menurut ketentuan Syariat Islam kepada para pedagang dan pegawai penjual daging ayam potong di pasar taradisional Kota Medan. Sedangkan target luarannya adalah terlatihnya para pedagang dan pegawai penjual daging ayam potong yang ada di pasar taradisional Kota Medan dalam melakukan penyembelihan hewan berdasarkan tuntunan Syariat Islam. Kemudian capaiannya adalah $100 \%$ peserta pelatihan mampu melakukan penyembelihan ayam potong secara benar menurut ketentuan Syariat Islam;

2. Solusi yang dilakukan dalam menyelesaikan permasalahan kedua adalah membentuk Kelompok Pedagang Cinta Produk Halal (KPCPH) di pasar tradisional Kota Medan yang disahkan oleh Ketua MUI Kota Medan yang memiliki tugas pokok: a. Melakukan penyembeliahan ayam potong sesuai ketentuan Syariat Islam, b. Melatih pedagang daging ayam potong dalam melakukan penyembelihan sesuai ketentuan Syariat Islam, c. Melaksanakan kerjasama dengan lembaga pemerintah terkait dalam penyaluran produk makanan halal di pasar tradisional Kota Medan. Adapun target luarannya adalah. Terbentuknya 3 (tiga) Kelompok Pedagang Cinta Produk Halal (KPCPH) di pasar tradisional Kota Medan yang disahkan oleh Ketua MUI Kota Medan yang susunan kepengurusannya terdiri dari:
Ketua, Sekretaris, Bendahara, dan 2 (dua) Anggota. Kemudian capaiannya adalah 3 (tiga) KPCPH dapat dibentuk di pasar tradisional Kota Medan berdasarkan SK Ketua MUI Kota Medan;

3. Solusi yang dilakukan dalam menyelesaikan permasalahan ketiga adalah menerbitkan sertifikat kelayakan melaksanakan penyembelihan hewan yang dikeluarkan oleh Ketua MUI Kota Medan terhadap pedagang daging ayam potong yang telah mengikuti pelatihan. Adapun target luarannya adalah . Menerbitkan sertifikat kelayakan melaksanakan penyembelihan hewan yang dikeluarkan oleh Ketua MUI Kota Medan terhadap pedagang daging ayam potong yang telah mengikuti pelatihan. Kemudian capaiannya adalah . 100\% peserta pelatihan penyembelihan hewan sesuai ketentuan MUI Kota Medan telah memperoleh sertifikat;

4. Solusi yang dilakukan dalam menyelesaikan permasalahan keempat adalah melaksanakan penyuluhan hukum tentang Tata Cara Penyembelihan ayam potong yang benar berdasarkan Syariat Islam di pasar tradisional Kota Medan sebagaimana diamanahkan oleh Undang-undang Nomor 33 Tahun 2014 Tentang Jaminan Produk Halal. Adapun target luarannya adalah membagikan Buku Panduan Tentang Tata Cara Penyembelihan Hewan Berdasarkan Syariat Islam dan meningkatkan pemahaman pedagang daging ayam potong 
tentang tata cara penyembelihan hewan berdasarkan Syariat Islam. Kemudian capaiannya adalah $100 \%$ buku panduan dapat didistribusikan kepada seluruh peserta dan $100 \%$ Masyarakat peserta PKM memahami materi yang disampaikan.

Solusi yang dilakukan untuk menyelesaikan permasalahan yang dihadapi pihak Majelis Ulama Kota Medan melalui pelaksanaan program PKM ini adalah:

Tabel 1. Solusi Penyelesaian Permasalahan Mitra dan Terget Luaran yang Diperoleh

\begin{tabular}{|c|c|c|c|}
\hline No & Solusi & Target Luaran & Capain \\
\hline 1 & $\begin{array}{l}\text { Solusi yang dilakukan dalam } \\
\text { menyelesaikan permasalan } \\
\text { pertama adalah dengan } \\
\text { melaksanakan pelatihan } \\
\text { tentang tata cara } \\
\text { penyembelihan ayam potong } \\
\text { secara benar menurut } \\
\text { ketentuan Syariat Islam } \\
\text { kepada para pedagang dan } \\
\text { pegawai penjual daging ayam } \\
\text { potong di pasar taradisional } \\
\text { Kota Medan }\end{array}$ & $\begin{array}{lr}\text { Terjadi peningkatan } \\
\text { pemahaman } \\
\text { pedagang dan pegawai } \\
\text { penjual daging ayam } \\
\text { potong yang ada di pasar } \\
\text { taradisional Kota Medan } \\
\text { dalam melakukan } \\
\text { penyembelihan hewan } \\
\text { berdasarkan tuntunan } \\
\text { Syariat Islam }\end{array}$ & \begin{tabular}{l}
$100 \%$ peserta \\
pelatihan mampu \\
melakukan \\
\multicolumn{2}{l}{ penyembelihan } \\
ayam potong \\
secara benar \\
menurut \\
ketentuan \\
Islam. Syariat
\end{tabular} \\
\hline 2 & $\begin{array}{l}\text { Solusi yang dilakukan dalam } \\
\text { menyelesaikan permasalahan } \\
\text { kedua adalah membentuk } \\
\text { Kelompok Pedagang Cinta } \\
\text { Produk Halal (KPCPH) di } \\
\text { pasar tradisional Kota Medan } \\
\text { yang disahkan oleh Ketua } \\
\text { MUI Kota Medan yang } \\
\text { memiliki tugas pokok: a. } \\
\text { Melakukan penyembeliahan } \\
\text { ayam potong sesuai } \\
\text { ketentuan Syariat Islam, b. } \\
\text { Melatih pedagang daging } \\
\text { ayam potong dalam } \\
\text { melakukan penyembelihan } \\
\text { sesuai ketentuan Syariat } \\
\text { Islam, c. Melaksanakan } \\
\text { kerjasama dengan lembaga } \\
\text { pemerintah terkait dalam } \\
\text { penyaluran produk makanan } \\
\text { halal di pasar tradisional } \\
\text { Kota Medan. }\end{array}$ & $\begin{array}{l}\text { Terbentuknya } 3 \text { (tiga) } \\
\text { Kelompok Pedagang } \\
\text { Cinta Produk Halal } \\
\text { (KPCPH) di pasar } \\
\text { tradisional Kota Medan } \\
\text { yang disahkan oleh } \\
\text { Ketua MUI Kota } \\
\text { Medan yang susunan } \\
\text { kepengurusannya terdiri } \\
\text { dari: Ketua, Sekretaris, } \\
\text { Bendahara, dan } 2 \text { (dua) } \\
\text { Anggota. }\end{array}$ & $\begin{array}{l}3 \text { (tiga) KPCPH } \\
\text { dapat dibentuk di } \\
\text { pasar tradisional } \\
\text { Kota Medan } \\
\text { berdasarkan SK } \\
\text { Ketua MUI Kota } \\
\text { Medan }\end{array}$ \\
\hline
\end{tabular}




\begin{tabular}{|c|c|c|c|}
\hline 3 & $\begin{array}{l}\text { Solusi yang dilakukan dalam } \\
\text { menyelesaikan permasalahan } \\
\text { ketiga adalah menerbitkan } \\
\text { sertifikat kelayakan } \\
\text { melaksanakan } \\
\text { penyembelihan hewan yang } \\
\text { dikeluarkan oleh Ketua MUI } \\
\text { Kota Medan terhadap } \\
\text { pedagang daging ayam } \\
\text { potong yang telah mengikuti } \\
\text { pelatihan }\end{array}$ & $\begin{array}{l}\text { Menerbitkan sertifikat } \\
\text { kelayakan melaksanakan } \\
\text { penyembelihan hewan } \\
\text { yang dikeluarkan oleh } \\
\text { Ketua MUI Kota Medan } \\
\text { terhadap pedagang } \\
\text { daging ayam potong } \\
\text { yang telah mengikuti } \\
\text { pelatihan }\end{array}$ & $\begin{array}{l}100 \% \text { peserta } \\
\text { pelatihan } \\
\text { penyembelihan } \\
\text { hewan sesuai } \\
\text { ketentuan MUI } \\
\text { Kota Medan telah } \\
\text { memperoleh } \\
\text { sertifikat }\end{array}$ \\
\hline 4 & $\begin{array}{l}\text { Solusi yang dilakukan dalam } \\
\text { menyelesaikan permasalahan } \\
\text { keempat adalah } \\
\text { melaksanakan penyuluhan } \\
\text { hukum tentang Tata Cara } \\
\text { Penyembelihan ayam potong } \\
\text { yang benar berdasarkan } \\
\text { Syariat Islam di pasar } \\
\text { tradisional Kota Medan } \\
\text { sebagaimana diamanahkan } \\
\text { oleh Undang-undang Nomor } \\
33 \text { Tahun 2014 Tentang } \\
\text { Jaminan Produk Halal }\end{array}$ & $\begin{array}{l}\text { 1. Buku Panduan } \\
\text { Tentang Tata Cara } \\
\text { Penyembelihan } \\
\text { Hewan Berdasarkan } \\
\text { Syariat Islam; } \\
\text { 2. Terjadinya } \\
\text { peningkatan } \\
\text { pemahaman pedagang } \\
\text { daging ayam potong } \\
\text { tentang tata cara } \\
\text { penyembelihan hewan } \\
\text { berdasarkan Syariat } \\
\text { Islam }\end{array}$ & $\begin{array}{l}\text { 1. } 100 \% \text { buku } \\
\text { panduan dapat } \\
\text { didistribusikan } \\
\text { kepada seluruh } \\
\text { peserta; } \\
\text { 2. } 100 \% \\
\text { Masyarakat } \\
\text { peserta PKM } \\
\text { memahami } \\
\text { materi yang } \\
\text { disampaikan }\end{array}$ \\
\hline
\end{tabular}

Ramlan dan Nahrowi dalam penelitiannya dengan judul:"Sertifikasi halal Sebagai Penerapan Etika Bisnis Islami dalam Upaya Perlindungan bagi Konsumen Muslim". Kesimpulan dari penelitian ini menunjukkan bahwa sertifikasi halal dalam makanan sangat dibutuhkan oleh konsumen Muslim untuk memberikan jaminan agar tidak mengkonsumsi atau menggunakan produk barang atau jasa yang tidak halal sehingga tidak terkena dosa.

Sertifikasi halal menjadi kewajiban negara untuk memproteksi hak-hak konsumen Muslim dari mengkonsumsi makanan, obatobatan dan kosmetika yang berasal dari jenis dan zat yang haram. Oleh karena itu perlu regulasi yang lebih jauh dan tegas untuk dapat menjangkau hak-hak konsumen
Muslim. Hal ini urgen untuk dilakukan mengingat tidak semua umat Muslim paham bahwa apa yang mereka konsumsi belumlah halal menurut hukum syariat. Disamping itu perlu juga untuk memberikan pemahaman, penegasan serta pengetahuan terhadap produsen untuk menjaga hak-hak konsumen Muslim. Sebagai negara dengan basis umat Islam terbesar di dunia sudah selaiknya para produsen lebih mementingkan tercapainya keamanan dan kenyamanan terhadap konsumen Muslim.

Penelitian Yusuf Sofie dalam penelitiannnya yang berjudul:" Jaminan atas Produk Halal dari Sudut Pandang Hukum Perlindungan Konsumen". Fokus perhatian penelitian ini terletak pada argumentasi mengapa diperlukan kepastian hukum atas produk halal di 
Indonesia. Uraian argumentasi di dalamnya menyangkut politik hukum pada tataran legislasi dan praksis yang dilakukan oleh Negara dalam konteks perlindungan konsumen di Indonesia. Dalam perspektif sub sistem (hukum) perlindungan konsumen di Indonesia, Pasal 8 ayat (1) huruf h Undangundang Nomor 8 Tahun 1999 tentang Perlindungan Konsumen seyogyanya menjadi rujukan utama untuk menentukan substansi yang diatur Undangundang Nomor 33 Tahun 2014 tentang Jaminan Produk Halal. Lebih lanjut Yusuf Sofie mengemukakan bahwa seyogyanya menjadi fokus perhatian dalam penegakan hukumnya agar harmonis dengan perundang-undangan perlindungan konsumen yang terlebih dahulu berlaku. Harmonisasi vertikal maupun horizontal atas substansi UU JPH 2014 yang telah dilakukan, seyogyanya menjadi perhatian pada tataran praksis.

Negara India telah melaksanakan sertikasi produk halal serta penerimaan positif dari masyarakat setempat. Keadaan lain dilaporkan di New Zealand bahwa sejumlah restoran setempat pun sangat memperhatikan pentingnya tersedianya produk halal di negara tersebut sehubungan dengan kedatangan para wisatawan dari negara-negara muslim. Negara Belanda, sama halnya dengan negara-negara Eropa lainnya, pasar bagi produk makanan halal sedang berkembang, bersesuaian dengan perundang-undangan makanan yang Islamis (islamic food laws).

Penelitian Eri Agustian H,dan Sujana yang berjudul:"Pengaruh Labelisasi Halal Terhadap Keputusan Pembelian Konsumen Studi Kasus pada Produk Wall's
Conello", menyimpulkn sebagai berikut: Hasil dari analisis pengaruh labelisasi halal terhadap keputusan pembelian konsumen yang beragama Muslim diperoleh kesimpulan bahwa keputusan pembelian terhadap produk Wall's Conello pada saat ini adalah 9,943, Sedangka pengaruh labelisasi halal terhadap keputusan pembelian konsumen yang beragama Non Muslim diperoleh persamaan regresi $\mathrm{y}=469,1) \quad 0 \quad(003,1469)$, dapat diartikan bahwa jika labelisasi halal adalah 1 maka keputusan pembelian akan meningkat sebesar 1,003, atau dengan kata lain dapat ditarik kesimpulan bahwa keputusan pembelian terhadap produk Wall's Conello pada saat ini adalah 1,469.

Ratih Kusuma Demi dalam skripsinya yang berjudul:"Studi Analisis Terhadap Sistem Jaminan Halal Produk pada IKM Bersertifikat Halal (Studi Kasus pada IKM di Kota Semarang)", menyimpulkan bahwa sebagai produsen, mutu dan keamanan makanan adalah hal mutlak yang harus diperhatikan oleh setiap pemilik usaha pada produk yang dihasilkan. Industri Kecil dan Menengah (IKM) yang bergerak di bidang makanan ringan atau olahan yang menjamin produknya dengan sertifikat halal di tuntut pula untuk menjaga sistem jaminan halal yang sudah ada dengan suatu sistem yang sudah dianjurkan oleh LPPOM MUI. Masyarakat diberikan peranan penting dalam penyelenggaraan jaminan produk halal sebagaimana diatur dalam Undang-undang Nomor 33 Tahun 2014 Pasal 53, ayat (1) bahwa masyarakat dapat berperan serta dalam penyelenggaraan Jaminan Produk Halal (JPH). Ayat (2) menyebutkan bahwa peran serta masyarakat sebagaimana dimaksud 
pada ayat (1) dapat berupa: a. Melakukan sosialisasi mengenai JPH, b. Mengawasi Produk dan Produk Halal yang beredar. Kemuadian ayat (3) berbunyi bahwa peran serta masyarakat berupa pengawasan Produk dan Produk Halal yang beredar sebagaimana dimaksud pada ayat (2) huruf b berbentuk pengaduan atau pelaporan ke BPJPH.

\section{KESIMPULAN}

Pelatihan tentang tatacara penyembelihan daging ayam potong menurut ajaran Islam merupakan sesuatu yang sangat dibutuhkan oleh masyarakat, terutama bagi masyarakat yang sering mengkonsumsi daging ayam potong. Sebab melalui penyembelihan daging ayam potong yang benar menurut ajaran Islam, akan sangat menentukan kriteria kehalalan daging ayam potong.

\section{REFERENSI}

Eri Agustian H,dan Sujana, (2013), Pengaruh Labelisasi Halal Terhadap Keputusan Pembelian Konsumen Studi Kasus pada Produk Wall's Conello, Jimkes Jurnal Ilmiah Manajemen Kesatuan, Vol. 1, No. 2.

Ramlan dan Nahrowi, (2014), Sertifikasi halal Sebagai Penerapan Etika Bisnis Islami dalam Upaya Perlindungan bagi Konsumen Muslim, Jurnal Ahkam, Vol. XIV, No. 1.

Ratih Kusuma Demi, (2015), Studi Analisis Terhadap Sistem Jaminan Halal Produk pada
IKM Bersertifikat Halal (Studi Kasus pada IKM di Kota Semarang), Skripsi, Universitas Islam Negeri Wali Songo.

Tengku Putri Lindung Bulan, (2016), Pengaruh Labelisasi Halal Terhadap Keputusan Pembelian Sosis di Kuala Simpang Kabupaten Aceh Tamiang, Jurnal Manajemen dan Keuangan, Vol. 5 No. 1.

Yusuf Sofie, (2015), Jaminan atas Produk Halal dari Sudut Pandang Hukum Perlindungan Konsumen, Jurnal Syariah 3, Nopember. 